\section{Response of In Vitro Strawberry to Silver Nitrate $\left(\mathrm{AgNO}_{3}\right)$}

Yonghua Qin and Shanglong Zhang ${ }^{1}$

Department of Horticulture, Zhejiang University, Key Laboratory of Horticultural Plant Growth, Development and Biotechnology, Ministry Agriculture, Hangzhou 310029, China

\author{
Lingxiao Zhang \\ Delta Research and Extension Center, Mississippi State University, P.O. Box \\ 197 Stoneville, MS 38756
}

\section{Daoyu Zhu \\ Department of Horticulture, Henan Agricultural University, Zhengzhou 450002 China}

\section{Asghar Syed \\ Department of Horticulture, Zhejiang University, Hangzhou 310029 China}

Additional index words. Fragaria $\times$ ananassa, $\mathrm{AgNO}_{3}$, shoot regeneration, antioxidant enzymes

\begin{abstract}
Response of Toyonoka strawberry to $\mathrm{AgNO}_{3}$ was studied. Types and combinations of plant growth regulators had significant effects on shoot regeneration efficiency. Explants cultured for 10 days in shoot regeneration medium in the presence of $\mathrm{AgNO}_{3}$ not only enhanced shoot regeneration efficiency but also expedited the initiation of adventitious buds. Highest regeneration $(87.38 \%)$ and number of shoots per explant (11.67) were achieved in shoot regeneration media containing $1.5 \mathrm{mg} \cdot \mathrm{L}^{-1} \mathrm{TDZ}, 0.4 \mathrm{mg} \cdot \mathrm{L}^{-1} \mathrm{IBA}$ and $1.0 \mathrm{mg} \cdot \mathrm{L}^{-1} \mathrm{AgNO}_{3}$. Half-strength MS containing $1.0 \mathrm{mg} \cdot \mathrm{L}^{-1} \mathbf{A g N O}_{3}$ was an optimum medium for rooting. $\mathrm{AgNO}_{3}$ advanced root emergence and increased percent rooting, root length, dry weight and activity. Lower concentrations of $\mathrm{AgNO}_{3}$ inhibited ethylene production and promoted shoot regeneration and growth. It had a significant stimulatory effect on chlorophyll, soluble protein contents and antioxidant enzyme activities. Chlorophyll and soluble protein contents, superoxide dismutase (SOD), peroxidase (POD) and catalase (CAT) activities were increased in the presence of $\mathrm{AgNO}_{3}$ and reached maximum at $1.0 \mathrm{mg} \cdot \mathrm{L}^{-1} \mathbf{A g N O}_{3} \cdot$ Root water content, superoxide free radicals $\left(\mathrm{O}_{2}^{-}\right)$, malondialdehyde (MDA) content, proline accumulation and IAA-oxidase activity in leaves were increased while (IAA) content was decreased in the presence of $\mathrm{AgNO}_{3}$ Chemical names used: indole-3-butyric acid (IBA); silver nitrate ( $\left.\mathrm{AgNO}_{3}\right)$; thidiazuron (TDZ); N6-benzyladenine (BA); 2,4-dichlorophenoxy acetic acid (2,4-D); indole3-acetic acid (IAA); $\alpha$-naphthalene acetic acid (NAA); gibberellic acid (GA $)$; bovine serum albumin (BSA); 2,3,5-triphenyl-2H-tetrazolium chloride (TTC).
\end{abstract}

Protocols for strawberry shoot regeneration in vitro have been reported (Lis, 1993; Passey et al., 2003); however, regeneration efficiency is low and inconsistent. Highly efficient regeneration method is one of the most important factors in determining the success of genetic transformation (Bandyopadhyay et al., 1999), further improvement of strawberry plant regeneration and establishment of a high-efficiency regeneration system would make a significant contribution to strawberry genetic research.

Being ethylene inhibitor, $\mathrm{AgNO}_{3}$ can markedly promote organogenesis, embryogenesis and shoot regeneration. It plays a significant role in somatic embryo production and shoot regeneration of durum wheat and maize (Carvalho et al.,

Received for publication 14 July 2004. Accepted for publication 26 Oct. 2004. This work was supported by the National Natural Science Foundation of China (No. 30170648). The authors thank Wei Guoqiang and Wang Ping for their excellent technical assistance.

${ }^{1}$ Professor; to whom reprint requests should be addressed; e-mail shlzhang@zju.edu.cn.
1997; Fernandez et al., 1999). With the addition of $\mathrm{AgNO}_{3}$ in medium, shoot regeneration efficiency was enhanced in sunflower (Yordanov et al., 2002), Arabidopsis (Márlon and Browse, 1991) and brassica (Pua et al., 1999). Organogenesis is a complex physiological and biochemical process associated with enzymatic, photosynthetic and endogenous growth regulators changes. Higher activities of antioxidant enzymes promote cell division and somatic embryogenesis (Cui et al., 1999; Tian et al., 2003). Relationship of antioxidant enzymes, MDA, chlorophyll and endogenous growth regulators to shoot regeneration is not well explored and little is known about the mechanism by which $\mathrm{AgNO}_{3}$ promotes organogenesis.
Shootregeneration capability of strawberry cultivars varies greatly and experiments need to be conducted to develop an optimized protocol for individual cultivars. In this study, Fragaria $\times$ ananassa Duch. 'Toyonoka' was used to define its regeneration capability and physiological responses to $\mathrm{AgNO}_{3}$ under in vitro conditions. The objectives of this study were to establish an efficient shoot regeneration system in the shortest possible time without entering callus phase, and to study the physiological effects of $\mathrm{AgNO}_{3}$ in strawberry. This highly efficient in vitro regeneration protocol will be a valuable tool in genetic transformation and other fundamental studies of strawberry.

\section{Materials and Methods}

Plant material and media. Runner tissues of strawberry were washed with tap water for $30 \mathrm{~min}$ and surface disinfected in $70 \%(\mathrm{v} / \mathrm{v})$ ethanol for $10 \mathrm{~s}$ and $0.1 \%(\mathrm{w} / \mathrm{v}) \mathrm{HgCl}_{2}$ for 5 to $8 \mathrm{~min}$, followed by four washes with sterile distilled water. Each time, tissues were soaked in water for $5 \mathrm{~min}$. Shoot tips of $0.2 \mathrm{~mm}$ were aseptically dissected out under a stereomicroscope and cultured on trigger medium for 3 to 4 weeks. Microshoots were transferred to proliferation medium and cultured for 3 weeks. Healthy and fully expanded strawberry leaves from plantlets were used in all experiments. After discarding apices, margins and midribs, 4 $\times 4$-mm explants were placed adaxially on the medium. MS medium (Murashige and Skoog, 1962) supplemented with $3 \%(w / v)$ sucrose and $0.7 \%(\mathrm{w} / \mathrm{v})$ agar with $\mathrm{pH} 5.8$ was used throughout the course of study. Fifteen factorial combinations of TDZ $(0.5,1.0,1.5,2.0,2.5$ $\left.\mathrm{mg} \cdot \mathrm{L}^{-1}\right)$, IBA $\left(0.2,0.4,0.6,0.8,1.0 \mathrm{mg} \cdot \mathrm{L}^{-1}\right)$ and 2,4-D $\left(0.2,0.4,0.6,0.8,1.0 \mathrm{mg} \cdot \mathrm{L}^{-1}\right)$ were tested for their effects on shoot regeneration. After screening various combinations of growth regulators, media were named based on the best combinations and used in the preceding experiments (Table 1). Leaf discs were cultured on shoot regeneration medium with 0, 0.5, 1.0,2.0,4.0 $\mathrm{mg} \cdot \mathrm{L}^{-1} \mathrm{AgNO}_{3}$ for $10 \mathrm{~d}$ and were transferred to the same medium without $\mathrm{AgNO}_{3}$. For rooting, shoots $(2.0 \mathrm{~cm}$ in length $)$ were separated and cultured on $1 / 2$-strength MS medium supplemented with 0 to $4.0 \mathrm{mg} \cdot \mathrm{L}^{-1}$ $\mathrm{AgNO}_{3}$.

Growth regulators and $\mathrm{AgNO}_{3}$ solutions were filter sterilized and added to the autoclaved medium in the aseptic conditions. Cultures were incubated at $25^{\circ} \mathrm{C} \pm 2{ }^{\circ} \mathrm{C}$ under $2000 \mathrm{Lx}$ irradiance (provided by fluorescent lamp, 36-W, Philips Electronic N.V., Holland) with $16-h$ photoperiod.

Enzyme extraction. Fresh leaves $(0.3 \mathrm{~g})$ were homogenized in an ice bath containing $3 \mathrm{~mL} 50 \mathrm{~mm}$ potassium phosphate buffer
Table 1. Medium and combinations of plant growth regulators.

\begin{tabular}{|c|c|c|}
\hline Medium & $\begin{array}{l}\text { Combinations of plant growth } \\
\text { regulators }\left(\mathrm{mg} \cdot \mathrm{L}^{-1}\right)\end{array}$ & Explant type \\
\hline Trigger mediun & $0.2 \mathrm{BA}+0.01 \mathrm{IBA}+0.1 \mathrm{GA}_{3}$ & Shoot-tips \\
\hline Prolif & $.5 \mathrm{BA}+0.03 \mathrm{NAA}$ & In vitro micro shoot-tips \\
\hline hoot regeneration & 1.5 & Leaf discs \\
\hline $\begin{array}{l}\text { Shoot regeneration plus } \mathrm{AgNO}_{3} \\
\text { Rooting medium }\end{array}$ & $\begin{array}{l}1.5 \mathrm{TDZ}+0.4 \mathrm{IBA}+1.0 \mathrm{AgNO}_{3} \\
\text { Half-strength } \mathrm{MS} \text { medium }+1.0 \mathrm{AgNO}\end{array}$ & $\begin{array}{l}\text { Leaf discs } \\
\text { Shoots }\end{array}$ \\
\hline
\end{tabular}


$(\mathrm{pH} 7.8+0.1 \mathrm{~mm}$ EDTA $+2 \%$ insoluble polyvinypolypyrrolidone). The homogenate was centrifuged at $15,000 \mathrm{~g}_{\mathrm{n}}$ for $15 \mathrm{~min}$ at 4 ${ }^{\circ} \mathrm{C}$. The supernatant was stored at $-20^{\circ} \mathrm{C}$ and used for assays of enzyme, $\mathrm{O}_{2}{ }^{-}$production and soluble protein.

Methods of determination. SOD analysis was conducted according to Giannopolitis and Ries (1997). POD and CAT activities were determined following Cakmak and Marschner (1991). MDA content was assayed using Popham and Novacky (1991 method. Soluble protein content was determined according to Bradford (1976) using BSA as a standard. Chlorophyll content was determined

Table 2. Effects of TDZ on shoot regeneration of strawberry. ${ }^{\mathrm{z}}$

\begin{tabular}{lcc}
\hline $\begin{array}{l}\text { TDZ } \\
\text { concn }^{y} \\
\left(\mathrm{mg} \cdot \mathrm{L}^{-1}\right)\end{array}$ & $\begin{array}{c}\text { Shoot } \\
\text { regeneration } \\
(\%)\end{array}$ & $\begin{array}{c}\text { Adventitious } \\
\text { buds/explant } \\
(\text { no. })\end{array}$ \\
\hline 0.5 & 25.45 & 1.29 \\
1.0 & 36.84 & 1.71 \\
1.5 & 45.45 & 2.10 \\
2.0 & 46.61 & 2.38 \\
2.5 & 47.45 & 2.68 \\
\hline
\end{tabular}

${ }^{\mathrm{z}}$ Linear regression of shoot regeneration and linear regression of number of adventitious buds per explant on TDZ concentration was significant at $\alpha \leq 0.05$.

${ }^{y}$ Murashige-Skoog medium with TDZ.

${ }^{x}$ The linear regression formula is $\mathrm{y}=10.754 \mathrm{x}+$ 24.229 .

${ }^{\mathrm{v}}$ The linear regression formula is $\mathrm{y}=0.69 \mathrm{x}+$ 0.997 .

Table 3. Effects of various IBA concentrations with constant TDZ concentrations on strawberry shoot regeneration efficiency. ${ }^{\mathrm{Z}}$

\begin{tabular}{cccc}
\hline \multicolumn{2}{c}{$\begin{array}{c}\text { Plant growth } \\
\text { regulator } \\
\left(\mathrm{mg} \cdot \mathrm{L}^{-1}\right)\end{array}$} & $\begin{array}{c}\text { Shoot } \\
\text { regeneration }\end{array}$ & $\begin{array}{c}\text { Adventitious } \\
\text { buds/explant } \\
\text { (no.) }\end{array}$ \\
\hline TDZ & IBA & & $\begin{array}{c}\text { IB) } \\
\text { TDZ }\end{array}$ \\
\hline 1.5 & 0.2 & 60.34 & 3.20 \\
1.5 & 0.4 & 76.67 & 5.78 \\
1.5 & 0.6 & 74.07 & 4.68 \\
1.5 & 0.8 & 67.27 & 4.49 \\
1.5 & 1.0 & 63.64 & 4.0 \\
\hline
\end{tabular}

2Polynomial regression of both shoot regeneration and number of adventitious buds per explant onIBA concentration was significant at $\alpha \leq 0.05$.

${ }^{\mathrm{y}}$ Murashige-Skoog medium with TDZ and IBA.

${ }^{x}$ The polynomial regression formula is $\mathrm{y}=-78.79 \mathrm{x}^{2}$ $+93.14 \mathrm{x}+47.18$.

vThe polynomial regression formula is $\mathrm{y}=-9.34 \mathrm{x}^{2}$ $+11.36 \mathrm{x}+1.72$

Table 4. Effects of various concentrations of 2,4-D with constant TDZ and IBA concentrations on strawberry shoot regeneration efficiency. ${ }^{z}$

\begin{tabular}{lcccc}
\hline & $\begin{array}{c}\text { Plant } \\
\text { growth } \\
\text { regulator } \\
\left(\mathrm{mg} \cdot \mathrm{L}^{-1}\right)\end{array}$ & & $\begin{array}{c}\text { Shoot } \\
\text { regeneration }\end{array}$ & $\begin{array}{c}\text { Adventitious } \\
\text { buds/explant }\end{array}$ \\
\hline TDZ & IBA & $2,4-\mathrm{D}$ & $(\%)$ & 1.86 \\
\hline 1.5 & 0.4 & 0.2 & 27.45 & 1.30 \\
1.5 & 0.4 & 0.4 & 17.54 & 1.17 \\
1.5 & 0.4 & 0.6 & 11.32 & 1.0 \\
1.5 & 0.4 & 0.8 & 6.78 & 0 \\
1.5 & 0.4 & 1.0 & 0 & no.) \\
\hline
\end{tabular}

${ }^{2}$ Linear regression of both shoot regeneration and number of adventitious buds per explant on 2,4-D concentration was significant at $\alpha \leq 0.05$.

${ }^{y}$ Murashige-Skoog medium with TDZ, IBA and 2,4-D.

${ }^{x}$ The linear regression formula is $\mathrm{y}=-32.83 \mathrm{x}+32.316$.

v The linear regression formula is $\mathrm{y}=-2.01 \mathrm{x}+2.272$. according to Arnon (1949). Superoxide free radicals $\left(\mathrm{O}_{2}^{-}\right)$production rate was measured spectrophotochemically by using the method described by Wang and Luo (1990). Ethylene production was detected according to Chen et al (1991). For root activities, TTC reduction procedure by Jiang and Zhu (1999) was followed. IAA content was measured according to Sweetser and Swartzfager (1978). Proline content was assayed by the photochemical method described by Bates et al (1973). For IAA-oxidase activity Lee (1971) method was used with minor modifications as follows. Fresh leaves $(0.5 \mathrm{~g})$ were homogenized in an ice bath containing a buffer solution with 5 $\mathrm{mL} 20 \mathrm{~mm}$ potassium phosphate $(\mathrm{pH} 6.1)$. The homogenate was centrifuged at 4,000 rpm for $20 \mathrm{~min}$ at $4{ }^{\circ} \mathrm{C}$ and stored under $-20^{\circ} \mathrm{C}$. To 1 $\mathrm{mL}$ of the crude enzyme extract, $2 \mathrm{~mL} 1 \mathrm{~mm}$ $\mathrm{MnCl}_{2}, 2 \mathrm{~mL} 1 \mathrm{~mm}$ 2,4-dichlorophenol, $2 \mathrm{~mL} 1$ mM IAA, and $3 \mathrm{~mL}$ potassium phosphate buffer (20 mM, pH6.1) were added. Solution was store at $25^{\circ} \mathrm{C}$ in the dark for $30 \mathrm{~min}$ and after addition of $4 \mathrm{~mL}$ Salkowski reagent (Pilet and Lavanchy, 1969), solution was again further stored at $25^{\circ} \mathrm{C}$ in the dark for $30 \mathrm{~min}$. IAAoxidase activity was determined by measuring the light spectrum at $530 \mathrm{~nm}$.

Statistical analysis. Data on shoot and root length, number of roots, rooting percentage, roots and shoots dry weight were recorded on the 21 st day of culture. Shoot regeneration efficiency was scored after $45 \mathrm{~d}$ in culture. Shoot regeneration experiment was repeated three times with 5 petri dishes and 60 explants per treatment and root induction experiment was repeated three times with 15 bottles consisting of 5 explants per bottle. Plant parts from root induction experiment were harvested for analysis of SOD, POD, CAT and IAA-oxidase activities, $\mathrm{O}_{2}^{--}$production rate, contents of soluble protein, IAA, MDA, proline and chlorophyll, root activities and ethylene production on the 21 st day of culture. Data were analyzed by SAS statistical package (SAS Inst., Cary, N.C.) and differences between treatment means were compared using LSD at $\alpha \leq 0.05$ probability level. Regression analysis was made for various concentrations of TDZ, with a constant level of TDZ $\left(1.5 \mathrm{mg} \cdot \mathrm{L}^{-1}\right)$ having various concentrations of IBA and with constant levels of TDZ and IBA (1.5 and $\left.0.4 \mathrm{mg} \cdot \mathrm{L}^{-1}\right)$ having various concentrations of 2,4-D respectively.
Effects of plant growth regulators on shoot regeneration. MS media supplemented with fifteen factorial combinations of TDZ, IBA and 2,4-D was used to select suitable levels for shoot regeneration of strawberry. Types and combinations of plant growth regulators had significant effect on regeneration of adventitious bud. TDZ at higher concentration promoted shoot regeneration efficiency but it also resulted in extended rates of vitrification. Maximum regeneration rate $(47.45 \%)$ was achieved with $2.5 \mathrm{mg} \cdot \mathrm{L}^{-1} \mathrm{TDZ}$ (Table 2). TDZ concentrations above $1.5 \mathrm{mg} \cdot \mathrm{L}^{-1}$ had an adverse effect on shoot regeneration. TDZ at $1.5 \mathrm{mg} \cdot \mathrm{L}^{-1}$ in combination with $0.2-0.4 \mathrm{mg} \cdot \mathrm{L}^{-1}$ IBA could markedly enhance the regeneration of adventitious buds(Table 3 ). At constant TDZ and IBA concentrations, all levels of 2,4-D had a negative effect on regeneration (Table 4). Explants ceased to induce shoots at $1.0 \mathrm{mg} \cdot \mathrm{L}^{-1}$ 2,4-D. Highest percent of shoot regeneration (76.67\%) and maximum number of shoots per explant (5.78) were achieved on MS medium supplemented with $1.5 \mathrm{mg} \cdot \mathrm{L}^{-1} \mathrm{TDZ}$ and 0.4 $\mathrm{mg} \cdot \mathrm{L}^{-1}$ IBA. All treatments induced calli during the first 2 weeks in culture.

Effects of $\mathrm{AgNO}_{3}$ on shoot regeneration. Effect of $\mathrm{AgNO}_{3}$ on shoot regeneration of strawberry was compared using MS medium with 1.5 $\mathrm{mg} \cdot \mathrm{L}^{-1} \mathrm{TDZ}$ and $0.4 \mathrm{mg} \cdot \mathrm{L}^{-1}$ IBA. Significant difference was observed in percent shoot regeneration and number of shoots per explant when explants were exposed to $\mathrm{AgNO}_{3}$ for $10 \mathrm{~d}$ (Table 5). Highest regeneration ( $87.38 \%$ ) and number of shoots per explant (11.67) were achieved with shoot regeneration media containing 1.5 TDZ, $0.4 \mathrm{IBA}$ and $1.0 \mathrm{mg} \cdot \mathrm{L}^{-1} \mathrm{AgNO}_{3}$. With $\mathrm{AgNO}_{3}$ in the medium, an earlier (5 to $7 \mathrm{~d}$ ) and stable shoot regeneration was observed, however higher concentrations $\left(\geq 2.0 \mathrm{mg} \cdot \mathrm{L}^{-1}\right)$ had negative effects on the general growth and development of explants associated with curly leaves, stunted growth and tissue browning. Explants did not produce shoots with $\mathrm{AgNO}_{3}$ concentrations at $6.0 \mathrm{mg} \cdot \mathrm{L}^{-1}$ (Fig. 1f).

Table 5. Regeneration capacity of adventitious buds of strawberry after preculturing in shoot regeneration medium with $\mathrm{AgNO}_{3}$ for $10 \mathrm{~d}{ }^{z}$

\begin{tabular}{lcc}
\hline $\begin{array}{l}\mathrm{AgNO}_{3}{ }^{\mathrm{y}} \\
\left(\mathrm{mg} \cdot \mathrm{L}^{-1}\right)\end{array}$ & $\begin{array}{c}\text { Shoot } \\
\text { regeneration } \\
(\%)\end{array}$ & $\begin{array}{c}\text { Adventitious } \\
\text { buds/explant }\end{array}$ \\
\hline 0 & $74.32 \mathrm{c}^{\mathrm{z}}$ & $\begin{array}{c}\text { (no.) } \\
0.5\end{array}$ \\
1.0 & $83.95 \mathrm{~b}$ & $9.06 \mathrm{~d}$ \\
2.0 & $87.38 \mathrm{a}$ & $11.67 \mathrm{a}$ \\
4.0 & $73.61 \mathrm{~d}$ & $6.81 \mathrm{c}$ \\
6.0 & $39.48 \mathrm{e}$ & $2.97 \mathrm{e}$ \\
\hline
\end{tabular}

"Polynomial regression of both "shoot regeneration" and "number of adventitious buds per explant" on $\mathrm{AgNO}_{3}$ concentration was significant at $\alpha \leq 0.05$. Means within a column followed by the same letters were not significantly different by SAS analysis using LSD at $\alpha \leq 0.05$.

${ }^{y}$ Murashige-Skoog medium with TDZ, IBA, and $\mathrm{AgNO}_{3}$.

${ }^{x}$ The polynomial regression formula is $\mathrm{y}=-2.49 \mathrm{x}^{2}$

$+0.97 \mathrm{x}+81.34$.

vThe polynomial regression formula is $\mathrm{y}=-0.34 \mathrm{x}^{2}$ $+0.59 \mathrm{x}+7.81$. 

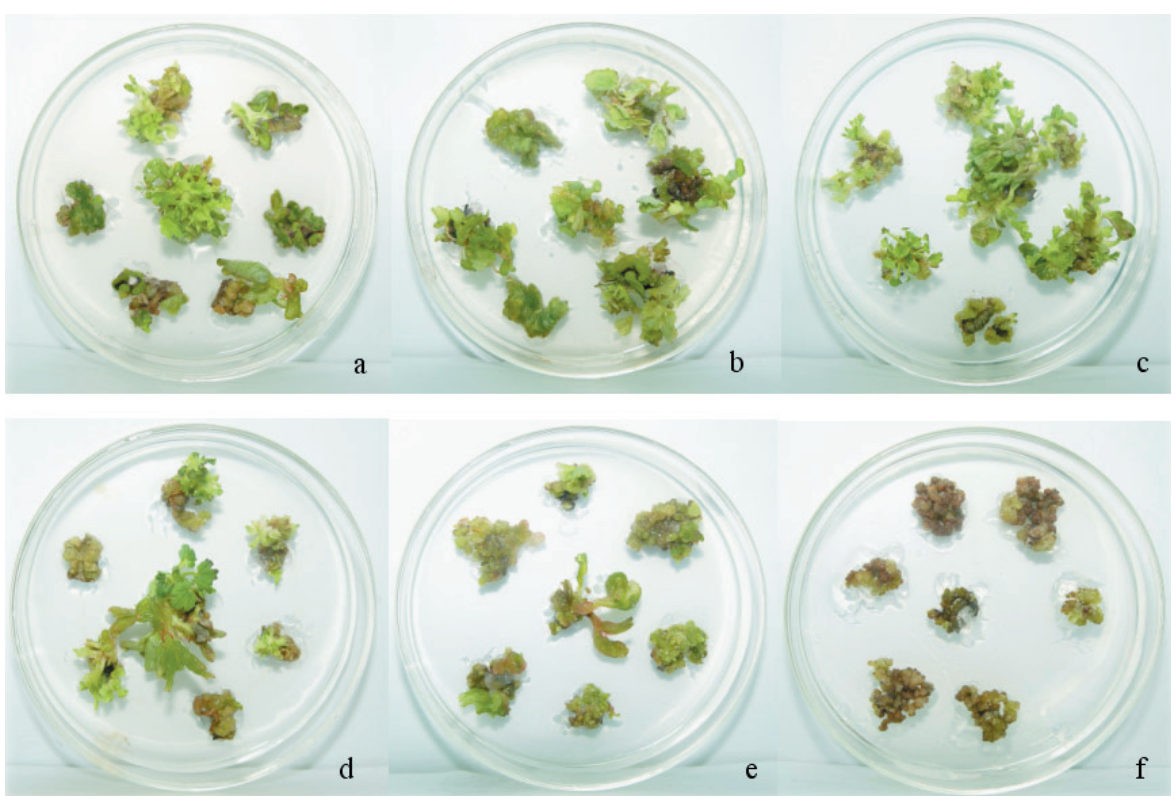

Fig.1. Shoot regeneration of strawberry cultured for $10 \mathrm{~d}$ in shoot regeneration medium with $\mathrm{AgNO}_{3}$. (a) $\mathrm{MS}+1.5 \mathrm{mg} \cdot \mathrm{L}^{-1} \mathrm{TDZ}+0.4 \mathrm{mg} \cdot \mathrm{L}^{-1} \mathrm{IBA}$, (b) MS + $1.5 \mathrm{mg} \cdot \mathrm{L}-1 \mathrm{TDZ}+0.4 \mathrm{mg} \cdot \mathrm{L}^{-1} \mathrm{IBA}+0.5 \mathrm{mg} \cdot \mathrm{L}^{-1}$ $\mathrm{AgNO}_{3}$, (c) $\mathrm{MS}+1.5 \mathrm{mg} \cdot \mathrm{L}^{-1} \mathrm{TDZ}+0.4 \mathrm{mg} \cdot \mathrm{L}^{-1} \mathrm{IBA}+1.0 \mathrm{mg} \cdot \mathrm{L}^{-1} \mathrm{AgNO}_{3}$, (d) $\mathrm{MS}+1.5 \mathrm{mg} \cdot \mathrm{L}^{-1} \mathrm{TDZ}+0.4$ $\mathrm{mg} \cdot \mathrm{L}^{-1} \mathrm{IBA}+2.0 \mathrm{mg} \cdot \mathrm{L}^{-1} \mathrm{AgNO}_{3}$, (e) $\mathrm{MS}+1.5 \mathrm{mg} \cdot \mathrm{L}^{-1} \mathrm{TDZ}+0.4 \mathrm{mg} \cdot \mathrm{L}^{-1} \mathrm{IBA}+4.0 \mathrm{mg} \cdot \mathrm{L}^{-1} \mathrm{AgNO}_{3}$, (f) $\mathrm{MS}+1.5 \mathrm{mg} \cdot \mathrm{L}^{-1} \mathrm{TDZ}+0.4 \mathrm{mg} \cdot \mathrm{L}^{-1} \mathrm{IBA}+6.0 \mathrm{mg} \cdot \mathrm{L}^{-1} \mathrm{AgNO}_{3}$.

Table 6. Rooting capacity and efficiency of strawberry as affected by $\mathrm{AgNO}_{3}$.

\begin{tabular}{|c|c|c|c|c|c|c|c|}
\hline $\begin{array}{l}\mathrm{AgNO} \\
\left(\mathrm{mg} \cdot \mathrm{L}^{-1}\right)\end{array}$ & $\begin{array}{l}\text { Root } \\
\text { emergence } \\
\text { peak } \\
\text { (d) }\end{array}$ & $\begin{array}{c}\text { Rooting } \\
(\%)\end{array}$ & $\begin{array}{l}\text { Root } \\
\text { length } \\
(\mathrm{cm})\end{array}$ & $\begin{array}{l}\text { Primary } \\
\text { roots } \\
\text { (no.) }\end{array}$ & $\begin{array}{l}\text { Root } \\
\text { dry wt } \\
\text { (g) }\end{array}$ & $\begin{array}{c}\text { Root } \\
\text { water } \\
\text { content } \\
(\%)\end{array}$ & $\begin{array}{c}\text { Root } \\
\text { activity } \\
{\left[\mathrm{TTF} \mu \mathrm{g} \cdot \mathrm{g}^{-1}\right.} \\
\left.(\text { fresh } \mathrm{wt}) \cdot \mathrm{h}^{-1}\right]\end{array}$ \\
\hline 1.0 & 6 & $93.68 \mathrm{a}$ & $14.32 \mathrm{a}$ & $10.08 \mathrm{a}$ & $0.046 \mathrm{a}$ & $85.58 \mathrm{ab}$ & $0.49 \mathrm{a}$ \\
\hline 2.0 & 7 & $86.29 \mathrm{~b}$ & $9.21 \mathrm{~b}$ & $7.17 \mathrm{~b}$ & $0.035 \mathrm{~b}$ & 84.96 b & $0.27 \mathrm{c}$ \\
\hline 4.0 & 8 & $79.77 \mathrm{c}$ & $7.18 \mathrm{c}$ & $7.0 \mathrm{~b}$ & $0.027 \mathrm{c}$ & $82.50 \mathrm{c}$ & $0.216 \mathrm{c}$ \\
\hline
\end{tabular}

${ }^{2}$ Means within a column followed by the same letters were not significantly different by SAS analysis using LSD at $\alpha \leq 0.05$.

Number of days was recorded when most of the shoots induced roots.

Effects of $\mathrm{AgNO}$, on rooting. Root primordia were observed after 5 to $6 \mathrm{~d}$ on rooting medium with optimum levels of $\mathrm{AgNO}_{3}$. Rooting was advanced 1 to $3 \mathrm{~d}$ as of the control (Table 6). Lower levels of $\mathrm{AgNO}_{3}$ markedly improved

root length, dry weight and root activities (Fig. 2). $\mathrm{AgNO}_{3}$ at $4.0 \mathrm{mg} \cdot \mathrm{L}^{-1}$ significantly reduced root length and dry weight, however, they were higher than that of the control. At $1.0 \mathrm{mg} \cdot \mathrm{L}^{-1}$ $\mathrm{AgNO}_{3}$, root length, dry weight and root ac-
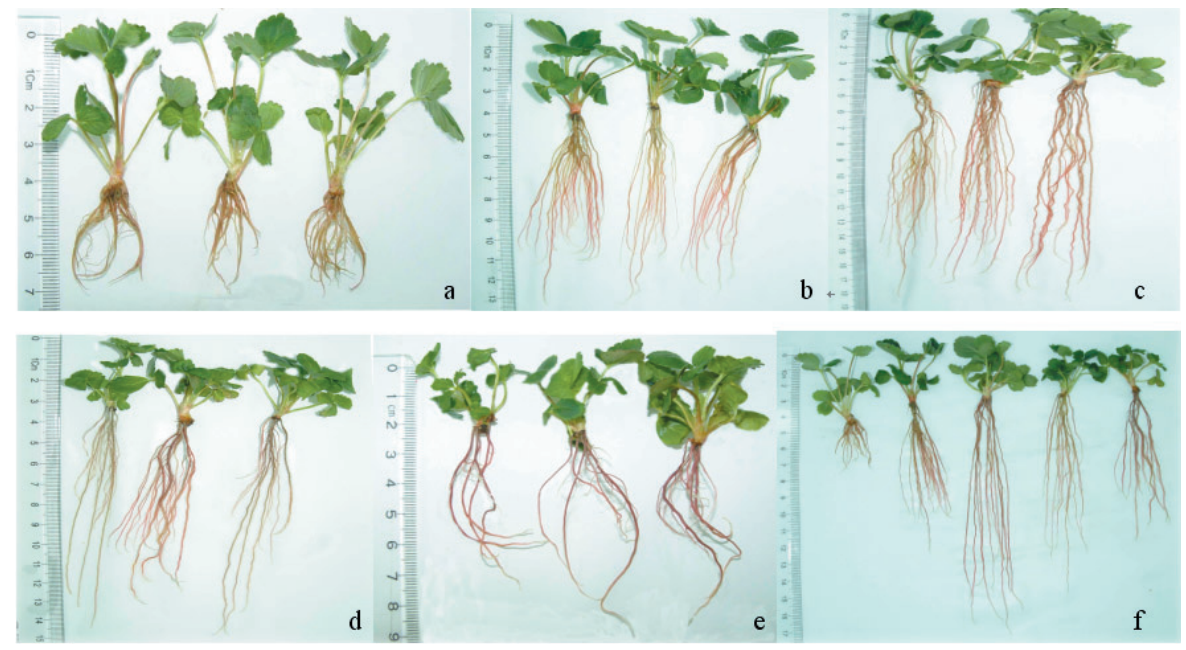

Fig.2. Effect of $\mathrm{AgNO}_{3}$ on growth of strawberry in vitro on half-strength MS medium supplemented with various concentrations of $\mathrm{AgNO}_{3}$. (a) $1 / 2 \mathrm{MS}$, (b) $1 / 2 \mathrm{MS}+0.5 \mathrm{mg} \cdot \mathrm{L}^{-1} \mathrm{AgNO}_{3}$, (c) $1 / 2 \mathrm{MS}+1.0 \mathrm{mg} \cdot \mathrm{L}^{-1}$ $\mathrm{AgNO}_{3}$, (d) $1 / 2 \mathrm{MS}+2.0 \mathrm{mg} \cdot \mathrm{L}^{-1} \mathrm{AgNO}_{3}$, (e) $1 / 2 \mathrm{MS}+4.0 \mathrm{mg} \cdot \mathrm{L}^{-1} \mathrm{AgNO}_{3}$, (f) $1 / 2 \mathrm{MS}+0,0.5,1.0,2.0$, and $4.0 \mathrm{mg} \cdot \mathrm{L}^{-1} \mathrm{AgNO}_{3}$. tivity were increased by $6.39,6.57$, and 2.13 times respectively. In contrast to the control, no significant effect of $\mathrm{AgNO}_{3}$ was observed on number of primary roots, root water content and rooting percentage below $1.0 \mathrm{mg} \cdot \mathrm{L}^{-1} \mathrm{AgNO}_{3}$. Higher concentrations of $\mathrm{AgNO}_{3}$ inhibited rooting efficiency and primary roots formation. Root water content reduced progressively with increasing $\mathrm{AgNO}_{3}$ concentration. It implied that $\mathrm{AgNO}_{3}$ could promote the development of root lignification.

Effects of $\mathrm{AgNO}_{3}$ on shoot growth. Stunted growth associated with shorter petioles and smaller leaves were observed in strawberry plants grown for $21 \mathrm{~d}$ in rooting medium with $\mathrm{AgNO}_{3}$. Compared with the control, no significant effect on shoot height was observed at $\leq 1.0 \mathrm{mg} \cdot \mathrm{L}^{-1} \mathrm{AgNO}_{3}$. Dry weights were gradually decreased in the presence of $\mathrm{AgNO}_{3}$

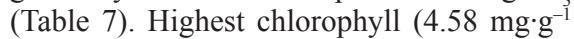
fresh weight) and soluble protein contents (521.80 $\mu \mathrm{g} \cdot \mathrm{g}^{-1}$ fresh weight) were recorded for $1.0 \mathrm{mg} \cdot \mathrm{L}^{-1} \mathrm{AgNO}_{3}$.

Effects of $\mathrm{AgNO}_{3}$ on $\mathrm{CAT}-\mathrm{SOD}-\mathrm{POD}$ activities, $\mathrm{O}_{2}^{-}$production rate and MDA contents. Significant differences of antioxidant enzyme activities, $\mathrm{O}_{2}^{-}$production rate and MDA contents were observed with the addition of $\mathrm{AgNO}_{3}$ in the medium. It had a significant stimula- 
Table 7. Shoot growth of strawberry as affected by $\mathrm{AgNO}_{3}$.

\begin{tabular}{lcccc}
\hline $\begin{array}{l}\mathrm{AgNO} \\
\left(\mathrm{mg} \cdot \mathrm{L}^{-1}\right)\end{array}$ & $\begin{array}{c}\text { Shoot ht } \\
(\mathrm{cm})\end{array}$ & $\begin{array}{c}\text { Shoot dry } \\
\mathrm{wt}(\mathrm{g})\end{array}$ & $\begin{array}{c}\text { Chlorophyll content } \\
\left(\mathrm{mg} \cdot \mathrm{g}^{-1} \text { fresh wt }\right)\end{array}$ & $\begin{array}{c}\text { Content of soluble protein } \\
\left(\mu \mathrm{g} \cdot \mathrm{g}^{-1} \text { fresh wt }\right)\end{array}$ \\
\hline 0 & $3.52 \mathrm{a}^{\mathrm{z}}$ & $0.097 \mathrm{a}$ & $4.286 \mathrm{ab}$ & $409.64 \mathrm{~b}$ \\
0.5 & $3.482 \mathrm{a}$ & $0.090 \mathrm{~b}$ & $3.72 \mathrm{bc}$ & $486.34 \mathrm{a}$ \\
1.0 & $3.62 \mathrm{a}$ & $0.0891 \mathrm{~b}$ & $4.58 \mathrm{a}$ & $521.80 \mathrm{a}$ \\
2.0 & $2.87 \mathrm{~b}$ & $0.075 \mathrm{c}$ & $3.68 \mathrm{bc}$ & $346.86 \mathrm{~b}$ \\
4.0 & $2.45 \mathrm{c}$ & $0.060 \mathrm{~d}$ & $3.48 \mathrm{c}$ & $254.67 \mathrm{c}$ \\
\hline
\end{tabular}

${ }^{2}$ Means within a column followed by the same letters were not significantly different by SAS analysis using LSD at $\alpha \leq 0.05$.

Table 8. CAT, SOD, POD activities, $\mathrm{O}_{2}^{-}$- production rate and MDA content of strawberry as affected by $\mathrm{AgNO}_{3}$.

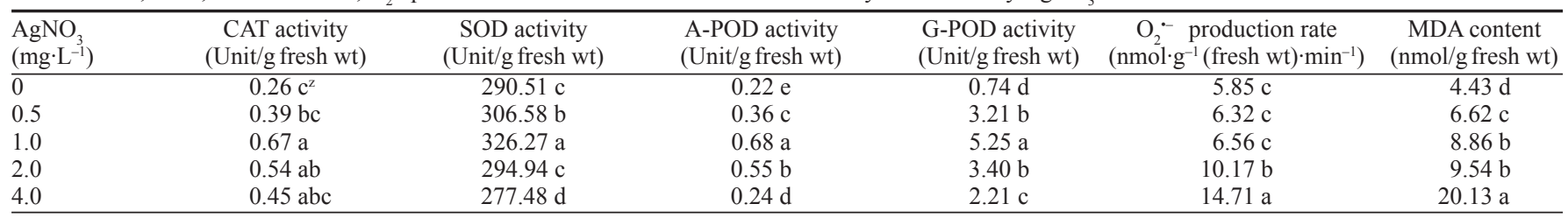

${ }^{2}$ Means within a column followed by the same letters were not significantly different by SAS analysis using LSD at $\alpha \leq 0.05$.

Table 9. Proline accumulation, IAA content, IAA-oxidase activity and ethylene production of strawberry as affected by $\mathrm{AgNO}_{3}$.

\begin{tabular}{lcccc}
\hline $\begin{array}{l}\mathrm{AgNO} \\
\left(\mathrm{mg} \cdot \mathrm{L}^{-1}\right)\end{array}$ & $\begin{array}{c}\text { Proline content } \\
\left(\mu \mathrm{g}^{-1} \text { fresh } \mathrm{wt}\right)\end{array}$ & $\begin{array}{c}\text { IAA content } \\
\left(\mu \mathrm{g} \cdot \mathrm{g}^{-1} \text { fresh } \mathrm{wt}\right)\end{array}$ & $\begin{array}{c}\text { IAA-oxidase activity } \\
(\mu \mathrm{g} \mathrm{IAA} / \mathrm{g}(\mathrm{FW}) / \mathrm{h})\end{array}$ & $\begin{array}{c}\text { Ethylene production } \\
\left(\mathrm{nL} \cdot \mathrm{g}^{-1} \cdot \mathrm{h}^{-1}\right)\end{array}$ \\
\hline 0 & $26.88 \mathrm{e} \mathrm{e}^{\mathrm{z}}$ & $1.72 \mathrm{a}$ & $14.72 \mathrm{e}$ & $1.07 \mathrm{c}$ \\
0.5 & $63.54 \mathrm{~d}$ & $1.49 \mathrm{~b}$ & $15.69 \mathrm{~d}$ & $0.72 \mathrm{~d}$ \\
1.0 & $73.89 \mathrm{c}$ & $1.30 \mathrm{c}$ & $16.11 \mathrm{c}$ & $0.55 \mathrm{~d}$ \\
2.0 & $78.18 \mathrm{~b}$ & $0.58 \mathrm{~d}$ & $18.08 \mathrm{~b}$ & $1.77 \mathrm{~b}$ \\
4.0 & $97.10 \mathrm{a}$ & $0.41 \mathrm{e}$ & $22.07 \mathrm{a}$ & $4.72 \mathrm{a}$ \\
\hline
\end{tabular}

${ }^{\mathrm{z}}$ Means within a column followed by the same letters were not significantly different by SAS analysis using LSD at $\alpha \leq 0.05$.

tory effect on antioxidant enzyme activities (Table 8). Maximum antioxidant enzyme activities were found in the presence of 1.0 $\mathrm{mg} \cdot \mathrm{L}^{-1} \mathrm{AgNO}_{3}$, as compared to the minimum at $4.0 \mathrm{mg} \cdot \mathrm{L}^{-1} \mathrm{AgNO}_{3}$. It was observed that the toxic effect of higher concentrations of $\mathrm{AgNO}_{3}$ could lead to necrotic leaves and darkened roots and poor plant growth. MDA content and $\mathrm{O}_{2}^{--}$production rate gradually increased with the addition of 0 to $1.0 \mathrm{mg} \cdot \mathrm{L}^{-1} \mathrm{AgNO}_{3}$ and sharply increased thereafter.

Effects of $\mathrm{AgNO}_{3}$ on proline accumulation, IAA content, IAA-oxidase activity and ethylene production. Significant differences in proline accumulation, IAA content and IAA-oxidase activity were observed during the growth of strawberry treated with $\mathrm{AgNO}_{3}$. Higher proline accumulation and IAA-oxidase activities had a positive relationship with $\mathrm{AgNO}_{3}$ concentration while IAA content had a negative relationship with $\mathrm{AgNO}_{3}$ (Table 9). Compared to the control, $\mathrm{AgNO}_{3}$ at 0.5 and $1.0 \mathrm{mg} \cdot \mathrm{L}^{-1}$ decreased ethylene production and promoted shoot regeneration and plant growth. There was no significant effect on ethylene production at $\leq 1.0 \mathrm{mg} \cdot \mathrm{L}^{-1} \mathrm{AgNO}_{3}$ concentration while $\geq 2.0$ $\mathrm{mg} \cdot \mathrm{L}^{-1} \mathrm{AgNO}_{3}$ significantly promoted ethylene production.

\section{Discussion}

Being a heavy ionic metal, $\mathrm{AgNO}_{3}$ had dual effects on shoot regeneration and growth of strawberry. In this experiment, $\mathrm{AgNO}_{3}$ at lower concentrations promoted shoot regeneration and plant growth. Lower concentrations of $\mathrm{AgNO}_{3}$ inhibited ethylene production and promoted shoot regeneration and plant growth while higher concentrations of $\mathrm{AgNO}_{3}$ promoted ethylene production. Ethylene disrupts auxin translocation, induces hyperhydricity, reduces chlorophyll content and causes tissue mortality (Lentini et al., 1988). It has been reported that $\mathrm{Ag}^{+}$interferes with the binding of ethylene receptor site and helps reduce ethylene production with promotion of polyamine biosynthesis (Roustan et al., 1990). The main function of $\mathrm{AgNO}_{3}$ is to eliminate the potential danger to plant cells and tissues in liverwort caused by ethylene (Elmo and Beyer, 1979). In light of these reports, results in this study clearly indicated that specific binding of $\mathrm{Ag}^{+}$ to certain ethylene receptors was most likely responsible for its stimulating effect on shoot regeneration and rooting.

Root is the major organ that absorbs water and nutrients. Root activity is an indicator of growth and vigor of the plants (Jiang and $\mathrm{Zhu}, 1999$ ). It has been reported that $\mathrm{AgNO}_{3}$ at the appropriate concentrations enhanced in vitro faba bean root number, root growth rate and root length (Mutasim and Kazumi, 2000). In this study, it was observed that $\mathrm{AgNO}_{3}$ at appropriate concentrations could promote rooting efficiency. Higher proline accumulation and IAA-oxidase activities had a positive relationship with $\mathrm{AgNO}_{3}$. In our case proline accumulation, SOD, CAT and POD activities were promoted in the presence of $\mathrm{AgNO}_{3}$. Antioxidant activities play a major role in plants scavenging system to get rid of $\mathrm{O}_{2}{ }^{-}, \mathrm{H}_{2} \mathrm{O}_{2}$, ${ }^{1} \mathrm{O}_{2}$ and $\cdot \mathrm{OH}$ during plant metabolism (Camp et al., 1997; Scandalios, 1993; Willekens and Inze, 1995). The $\mathrm{O}^{-}{ }^{-}$and MDA cause severe damage to plant cell. The former causes lipid peroxidation while the latter is a product of 
membrane lipid peroxidation (Jiang et al., 1994). In our case, lower concentrations of $\mathrm{AgNO}_{3}$ improved plant defense mechanism. $\mathrm{O}^{-}-$and MDA content significantly increased while antioxidant activities decreased in the presence of higher $\mathrm{AgNO}_{3}$ concentrations. This may be due to the accumulation of $\mathrm{H}_{2} \mathrm{O}_{2}$ and high oxidation of membrane lipids.

In this experiment, IAA-oxidase activity and proline accumulation were increased with $\mathrm{AgNO}_{3}$ while endogenous IAA content decreased. Reason for increasing rooting efficiency maybe attributed to the lower endogenous IAA content. Inverse-correlation between IAA content and IAA-oxidase activity was found in this study, which is in agreement with Jasdawala et al. (1977). IAA-oxidase is one of the key enzymes to regulate endogenous IAA level and interfere in auxin biosynthesis (Reinecke and Bandurski, 1988). Stresses induced proline accumulation in plants. Proline is involved in releasing stresses; protection of enzymes, organizing cellular structure and act as a free radical scavenger, but its specific role still remains a controversial subject (Delauney and Verma, 1993; Rensburg et al., 1993). In this study, proline content significantly increased in the presence of $\mathrm{AgNO}_{3}$, which may have helped in protection of plant tissues from the toxic effects of $\mathrm{AgNO}_{3}$. These findings confirm the previous reports stating that proline accumulation is helpful for plant to resist stresses (Delauney and Verma, 1993; Rensburg et al., 1993). The role of $\mathrm{AgNO}_{3}$ in plant organogenesis has not yet been clearly understood and further research needs to be carried out.

\section{Literature Cited}

Arnon, D.L. 1949. Copper enzyme in isolated chloroplast polyphenol oxidase in Beta vulgaris. Plant Physiol. 24:1-15.

Bandyopadhyay, S., K. Cane, G. Rasmussen, and J.D. Hamill. 1999. Efficient plant regeneration from seedling explants of two commercially important temperate eucalypt species Eucalyptus nitens and E. globilus. Plant Sci. 140:189-198.

Bates, L.S., R.P. Waldren, and I.D. Teare. 1973. Rapid determination of free proline for water-stress studies. Plant Soil 39:205-207.

Bradford, M.M. 1976. A rapid and sensitive method for the quantitation of microgram quantities protein utilizing the principle of protein-dye binding. Anal Biochem. 72:248-259.
Cakmak, I. and H. Marschner. 1991. Magnesium deficiency and high light intensity enhance activities of superoxide dismutase ascorbate peroxidase, and glutathione reductase in bean leaves. Plant Physiol. 98:1222-1227.

Camp, W.V., D. Inza, and M.V. Montagu. 1997. The regulation and function of tobacco superoxide dismutase Free Radical. Biol. Med 23:515-520.

Carvalho, C.H.S., N. Bohorova, P.N. Bordallo, L.L. Abreu, F. H. Valicente, W. Bressan, and E. Paiva. 1997. Type II callus production and plant regeneration in tropical maize genotypes. Plant Cell Rpt. 17:73-76.

Chen, K.S., L. Yu, and S.T. Zhou. 1991. A study on controlled atmosphere storage of "Ya-Li" pears. Acta Hort. Sinica 18:131-137.

Cui, K.R., G.M. Xing, X.M. Liu, and Y.F. Wang. 1999. Effect of hydrogen peroxide on somatic embryogenesis of Lysium barbarum L. Plant Sci. 146:9-16.

Delauney, A.J. and D.P.S. Verma. 1993. Proline biosynthesis and osmoregulation in plants. Plant $\mathrm{J}$. 4: 215-223.

Elmo, M. and T.R. Beyer. 1979. Effect of silver ion, carbon dioxide and oxygen on ethylene action and metabolism. Plant Physiol. 63:169-173.

Fernandez, S., N. Michaux-Ferrière, and M. Coumans. 1999. The embryogenic response of immature embryo cultures of durum wheat (Tritium durum Desf.): Histology and improvement by $\mathrm{AgNO}_{3}$. Plant Growth Regulation 28:147-155.

Giannopolitis, C.N. and S.K. Ries. 1977. Superoxide dismutases I. Occurrence in higher plants. Plant Physiol. 59:309-314.

Jasdawala, R.T., Y.D. Singh, and J.J. Chinoy. 1977. Auxin metabolism in developing cotton hairs. J. Expt. Bot. 28:1111-1116.

Jiang and Zhu. 1999. Plant physiological experimental guide, p. 92-93. Chengdu University of Science and Technology Press.

Jiang, M.Y., W.Y. Yang, J. Xu, and Q.Y. Chen. 1994. Active oxygen damage effect of chlorophyll degradation in rice under osmotic stress. Acta Botanica Sinica 36:289-295.

Lee,T.T. 1971.Cytokinin-controlled indole acetic acid oxidase isoenzymes in tobacco callus cultures. Plant Physiol. 47:181-185.

Lentini, Z., H. Mussell, M.A. Mutschler, and E.D. Earle. 1988. Ethylene generation and reversal of ethylene effects during development in vitro rapid-cycling Brassica campertris L. Plant Sci. 54:75-81.

Lis, E.K. 1993. Strawberry plant regeneration by organgenesis from peduncle and stolon segments. Acta Hort. 348:435-438.

Márlon, L. and J. Browse. 1991. Fascicle transformation of Arabidopsis. Plant Cell Rpt. $10: 235-239$
Murashige, T. andF. Skoog. 1962. Arevised medium for rapid growth and bioassays with tobacco tissue culture. Plant Physiol. 15:473-497.

Mutasim, M.K. and H. Kazumi. 2000. Ethylene inhibitors enhance in vitro root formation on faba bean shoots regenerated on medium containing thidiazuron. Plant Growth Regulat. 32:59-63.

Passey, A.J., K.J. Barrett, and D.J. James. 2003. Adventitious shoot regeneration from seven commercial strawberry cultivars (Fragaria $\times$ ananassa Duch.) using a range of explant types. Plant Cell Rpt. 21:97-401.

Pilet, P.E. and P. Lavanchy. 1969. Purification d'extraits peroxydasiques (Racine de Lens) à activité 'auxines -oxydsasique', Physiol. Vég. 7:19-29.

Popham, P.L. and A. Novacky. 1991. Use of dimethyl sulfoxide to detect hydroxyl radical during bacteria-induced hypersensitive reaction. Plant Physiol. 96:1157-1160.

Pua, E.C, X.Y. Deng, and K.A.T. Chew. 1999. Genotypic variability of de novo shoot morphogenesis of Brassica oleracea in vitro in response to ethylene inhibitors and putrescine. J. Plant Physiol. 155:598-605.

Reinecke, D.M. and R.S. Bandurski. 1988. Oxidation of indole-3-acetic acid to oxindole-3-acetic acid by an enzyme preparation from Zea mays. Plant Physiol. 86: 868-872.

Rensburg, L.V., G.H.J. Kruger, and H. Kruger. 1993. Proline accumulation as drought-tolerance selection criterion: its relationship to membrane integrity and chloroplast ultrastructure in Nicotiana tabacum L. J. Plant Physiol. 141:188-194.

Roustan, J.P., A. Latche, and J. Fallot. 1990. Inhibition of ethylene production and simulation of carrot somatic embryogenesis by salicylic acid. Biologia Plantaru 32:273-276.

Scandalios, J.G. 1993. Oxygen stress and superoxide dismutases. Plant Physiol. 101:7-12.

Sweetser, P.B. and D.G. Swartzfager. 1978. Indole-3acetic acid levels of plant tissue as determined by a new high performance liquid chromatographic method. Plant Physiol. 6:1254-258

Tian, M., Q. Gu, and M.Y. Zhu. 2003. The involvement of hydrogen peroxide and antioxidant enzymes in the process of shoot organgenesis of strawberry callus. Plant Sci. 165:701-707.

Wang, A.G. and G.H. Luo. 1990. Quantitative relation between the reaction of hydroxylamine and superoxide anionradicals in plants. Plant Physiol. Commun. 26:55-57.

Willekens, H. and D. Inze. 1995. Catalyses in plants. Mol. Breed. 1:207-228.

Yordanov, Y., E. Yordanova, and A. Atanassov. 2002. Plant regeneration from interspecific hybrid and backcross progeny of Helianthus eggertii $\times$ Helianthus annuis. Plant Cell Tissue Org. Cult. 71: 7-14. 